\title{
Marketing Mix Influencing Organic Foods Purchase of Mexican Consumers*
}

\author{
Lizbeth Salgado-Beltrán \\ University of Sonora, Caborca, Mexico \\ Joel Enrique Espejel-Blanco \\ University of Sonora, Hermosillo, Mexico \\ Luis Felipe Beltrán-Morales \\ Northwestern Biological Research Center, La Paz, Baja California Sur, Mexico
}

\begin{abstract}
The company to sensitize environmentally to its potential market can use price, product, distribution, and communication. This study provides market-evidence on how to approach Mexican consumers, regarding marketing mix and its effects on organic foods purchase. The main goal is to contribute to an analysis of causes-effects on consumer perceptions based on the Structural Equations Model (SEM). In order to contrast the hypothesis, data were obtained using a structured questionnaire based on a five-point Likert scale $(n=383)$. We rejected hypothesis 1 , the price has a positive and significant effect on organic foods purchase $(-0.23, p<0.002)$.
\end{abstract}

Keywords: organic food purchase, marketing mix, Mexican consumers, structural equations model

\section{Introduction}

The demand for organic foods, defined as those who do not use synthetic chemicals instead they are natural origin that is readily biodegradable, low-impact or can be recycled (e.g., packaging, packaging and labeling) began to expand dramatically in developed countries in the late eighties. In Mexico, development of organic agriculture started in the 1960s, through foreign agents, connecting to different Mexican operators (Schwentesius, Nelson, \& Gómez-Cruz, 2010, p. 1). At present, the organic sector has grown dynamically, despite the economic crisis. For example, organic area between 1996 and 2008 reached an annual growth above 3\% and employment in the sector increased 26\% per year (Gómez-Cruz et al., 2009, p. 12).

Environmental awareness has spread to businesses, institutions, and society in general, but although these efforts, the situation of the environment on a global scale cannot be said to have improved, consumers have not left their traditional brands and only a segment of people are consistent in their interests on the environment

\footnotetext{
*Acknowledgment: The authors would like to acknowledge the sponsorship of the Consejo Nacional de Ciencia y Tecnología (CONACYT) via Complementary Support Program for Institutional Consolidation of Research Groups 2010, retention mode 144682.

Lizbeth Salgado-Beltrán, Ph.D. in Economics, Research Professor, Department of Economics and Business Sciences, University of Sonora.

Joel Enrique Espejel-Blanco, Ph.D. in Economics, Research Professor, Department of Economics, University of Sonora.

Luis Felipe Beltrán-Morales, Doctor of Science, Research Professor, Northwestern Biological Research Center.

Correspondence concerning this article should be addressed to Lizbeth Salgado-Beltrán, Department of Economics and Business Sciences, Ave. Universidad e Irigoyen, Col. Ortiz, Caborca, Sonora, C.P. 83600, Mexico. E-mail: lsalgado@caborca.uson.mx.
} 
(Salgado-Beltrán, Subirá-Lobera, \& Beltrán-Morales, 2011, p. 4). So, company can sensitize environmentally to its potential market using price, product, distribution, and communication strategies. These factors have been investigated as influences of the purchase decision: price strategies (Bhate \& Lawler, 1997; L. K. Mathur, \& I. Mathur, 2000; Moon et al., 2002; Tung et al., 2012), product strategies (Martinsons et al., 1997; Chen, 2001; Handfield et al., 2001; Pujari, Wright, \& Peattie, 2003; De Caluwe, 2004; Bhaskaran et al., 2006; Jansen \& Stevels, 2006; De Ferran \& Grunert, 2007), distribution strategies (Handfield et al., 2001) and communication strategies (Carlson, Grove, \& Kangun, 1993; Banerjee, Gulas, \& Iyer, 1995; Carlson \& Grove, 1996; Mohr, Eroglu, \& Ellen, 1998; Wagner \& Hansen, 2002; Lankard \& McLaughlin, 2003) but not altogether in cause-effect analysis.

This study provides market-evidence on how to approach Mexican consumers, regarding marketing mix and its effects on organic foods purchase. This paper is organized as follows. In section two we are briefly revising the elements of the theoretical model. Section three presents a design research of the relationship between marketing mix and organic foods purchase. Section four presents the investigation results and section five summarizes the main conclusions.

\section{Literature Review}

In this section, we briefly define some basic concepts to be used throughout the paper and we present theoretical model (see Figure 1). There have been numerous publications related to organic foods purchase (Montoro-Rios et al., 2006), specifically in the early 90’s increases their strength (Schahn \& Holzer, 1990; W. E. Stead, J. G. Stead, \& Worrell, 1991; Banerjee, Gulas, \& Iyer, 1995; Govidnasamy \& Italia, 1999) to keep growing since then (De Ferran \& Grunert, 2007; Chen, 2007, Bansal, 2008; Grundey \& Zaharia, 2008; Hartmann, Apaolaza-Ibáñez, \& Forcada-Sainz, 2005; Ojala, 2008; Gifford \& Bernard, 2011; Tung et al., 2012).

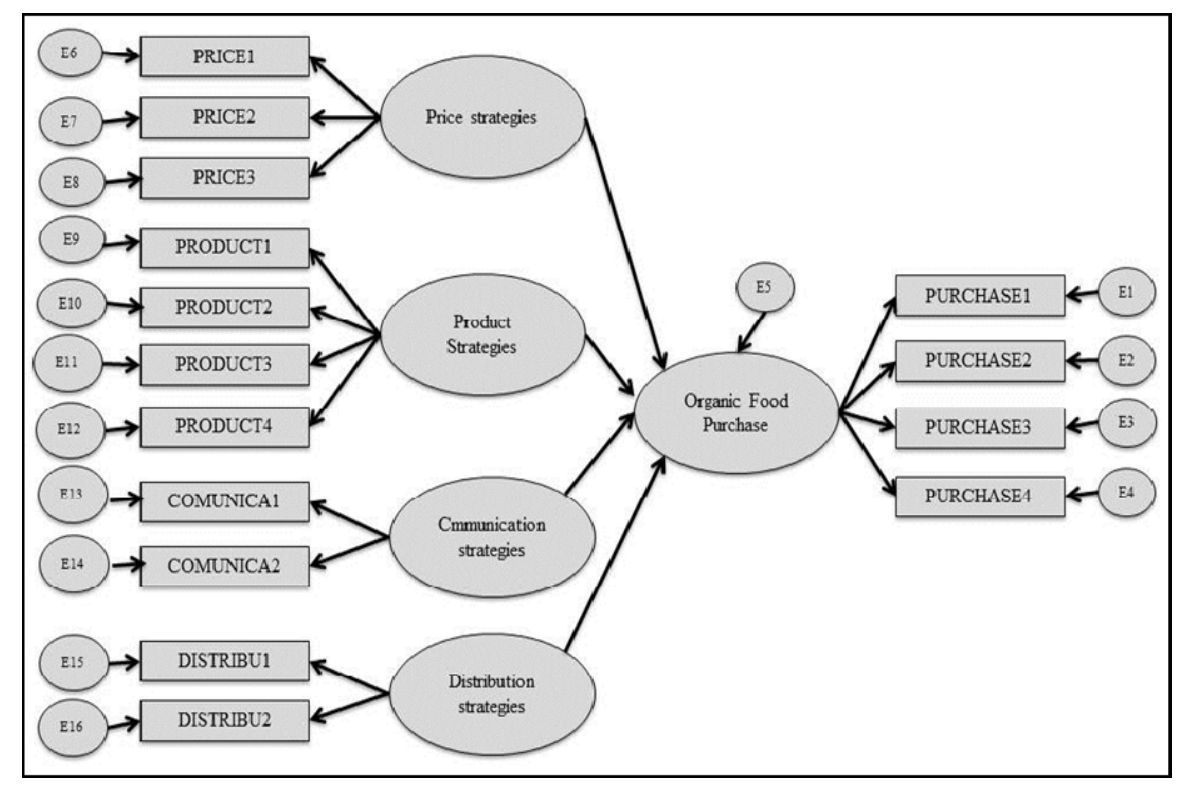

Figure 1. Theoretical model.

\section{Defining Price}

Any product or service has a price, and conceptually, is defined as the expression of value that is assigned 
to that product or service in monetary terms. The variable price is one of the most important and elemental variables in an organic foods purchase (Bhate \& Lawler, 1997). In Mexico, organic foods price is very varied, between $10 \%$ and 200\% (economy and premium price strategies) (Salgado-Beltrán, Subirá-Lobera, \& Beltrán-Morales, 2009). Information plays an important role in willing to pay (WTP) (Hawken, 1993). Gifford and Bernard (2011) found out that the effects of presenting information prior purchase organic products increased by $50 \%$ of participants the WTP. Besides that those who were female, who had higher occupation prestige, who had college education levels, who were aged in their 40's, and who possessed an optimistic opinion toward the necessity of organic farming tend to pay a premium for and buy organic food (Tung et al., 2012, p. 1003). However, the likelihood of paying a premium for organic produce decreases with the number of individuals living in the household (Govindasamy \& Italia, 1999).

\section{Defining Product}

The basic rules of International Federation of Organic Agriculture Movements (IFOAM) use the terms ecologic products and organic as equivalent. As we can see an organic product is one that performs the same functions of the equivalent foods, but the damage to the environment is less to do over its life cycle (Martinsons et al., 1997; Chen, 2001; Handfield et al., 2001; Pujari, Wright, \& Peattie, 2003; De Caluwe, 2004; Bhaskaran et al., 2006; Jansen \& Stevels, 2006; De Ferran \& Grunert, 2007). So the attributes of freshness and nutrition of ecologic product are highlighted by consumers and the greater propensity to buy organic products is between fresh and well-educated young women (Wier \& Mørch, 2001). The certifications are another attributes; they have emerged as one of the main tools of green marketing. It must be credible process if: (1) it assures consumers that organic food is produced according to rules to protect environment; (2) the producers unscrupulous will not use the term organic; and (3) it makes that market more efficient in the marketing channel from producer to consumer (Lohr, 1998).

\section{Defining Distribution}

This part would cover the environmental impacts related to packaging, transport, and distribution of good to its user (Azqueta, 2002). Nowadays the limited awareness and unavailability of organic foods and services inhibit the green consumerism (Martinsons et al., 1997; Handfield et al., 2001). Therefore, the distribution systems should be evaluated and designed according to a global result, not to the comparisons between the isolated parts for ecological benefit. As well as the implications for businesses and consumers that could originate, as they may affect the competitiveness as a whole.

\section{Defining Communication}

It is important to inform consumers about the benefits of organic foods. If credible and verifiable, it can help consumers feel they are making a difference to buying the product. The environmental ads can be expressed as a relationship between a product or service and the environment, and can promote a green lifestyle (Wagner \& Hansen, 2002, p. 20). Further communication and policy modification are needed to reinforce consumers' confidence in organic agriculture/food (Tung et al., 2012, p. 997).

\section{Defining Organic Foods Purchase}

The organic foods purchase is understood to choose products based on their production process, content, packaging, recyclability, type of waste generated, and regulations (Calomarde, 2000, p. 15). That is, a purchase based on environmental awareness to reduce sources of waste, promote recycling, and take care about health. 


\section{Methodology}

In order to contrast the hypothesis, data were obtained using a structured questionnaire based on a five-point Likert scale. Sampling was performed at sale points of the supermarkets. We used the formula for infinite populations, segmenting the population aged 18 to 65 obtaining a sample size of 383 valid cases, with a sample error $\pm 5 \%$ and confidence level of $95.5 \%$.

The organic food purchase can be observed directly, someone buys the product or not buys it. However, several studies have established marketing constructs on aspects that may explain why we buy a product (Stead et al., 1991; Tung et al., 2012). In this case we developed four constructs from a business management approach (price, product, communication, and distribution) to be related to the organic food purchase construct.

Data analysis was made by Structural Equation Models (SEM) that determined in the same analysis as relation between manifest and latent variables, so relationships between latent variables, and allows it to test a set of proposed relations - a theoretical model —against the manifest relations that is to say, the data (Bentler, 1995; Schumacker \& Lomax, 1996; Bazán et al., 2006).

The inner model and the outer model confirm an SEM. First, it specifies the directional relationship between the latent variables, that is to say, equations that express relationships between factors, whose representation is:

$$
\eta=B \eta+\Gamma \xi+\zeta
$$

where:

$\eta: m x 1$ vector of endogenous latent variables;

$B: m x m$ coefficient matrix of the endogenous variables;

$\Gamma$ : $m x k$ coefficient matrix of the exogenous variables;

$\xi: k x 1$ vector of exogenous latent variables;

$\zeta: m x 1$ vector of random disturbance terms.

Second, it specifies the relationships that keep the factors or latent variables with their respective indicators, as specified relationships between observable and latent variables in a confirmatory factor analysis, that is to say, measurement equations of these factors, whose representation in equation form is:

$$
\begin{aligned}
& \Upsilon=\Lambda y \eta+\varepsilon \\
& \mathrm{X}=\Lambda x \xi+\delta
\end{aligned}
$$

where:

$\eta$ : $m x 1$ vector of endogenous latent variables;

$\xi: k x 1$ vector of exogenous latent variables;

$\Lambda x: q x k$ coefficient matrix of the exogenous variables;

$\Lambda y:$ pxm coefficient matrix of the endogenous variables;

$\delta: q x 1$ measurement error vector for exogenous indicators;

$\varepsilon: p x 1$ measurement error vector for endogenous indicators.

\section{Hypotheses}

Consumers are willing to pay (WTP) a premium price for organic foods but they are not sufficiently involved with environmental issues (Bhate \& Lawler, 1997; Moon et al., 2002; Gifford \& Bernard, 2011). We may thus propose the following hypotheses:

$\mathrm{H}_{1}$ : The price has a positive and significant effect on organic foods purchase. 
$\mathrm{H}_{2}$ : The product has a positive and significant effect on organic foods purchase.

To generate an organic foods purchase is necessary to use a tool of persuasion, communication, if companies do not report the environmental costs of production to consumers, is an effect of incomplete information (Hawken, 1993). Upon receiving this information completely, the propensity to change in attitude could be higher (Wagner \& Hansen, 2002, p. 18). Thus, the following hypotheses are formulated:

$\mathrm{H}_{3}$ : The communication has a positive and significant effect on organic foods purchase.

$\mathrm{H}_{4}$ : The distribution has a positive and significant effect on organic foods purchase.

\section{Data Analysis and Finding}

Subsequently, we estimated the structural equation model by Robust Maximum Likelihood method. We used the statistical software AMOS version 19.0.

\section{Procedure}

It evaluates the measurement model through analysis of reliability of the item by an Exploratory (EFA) and Confirmatory Factor Analysis (CFA), in the first, it depurate scales and its items preparing CFA (see Table 1). For example, for the first indicator PURCHASE1 represents a communality of $\lambda^{2}=0.801$, indicating that $80 \%$ of variance of manifest variable is connected with construct Organic Food Purchase (see Table 1).

Table 1

Individual Item Reliability

\begin{tabular}{lclccc}
\hline Organic food purchase & $\begin{array}{l}\text { Communality } \\
\lambda^{2}\end{array}$ & Price strategy & $\begin{array}{l}\text { Communality } \\
\lambda^{2}\end{array}$ & Product strategy & $\begin{array}{l}\text { Communality } \\
\lambda^{2}\end{array}$ \\
\hline \multicolumn{2}{c}{ Item } & & Item & Item \\
\hline PURCHASE1 & 0.801 & PRICE1 & 0.885 & PRODUCT1 & 0.786 \\
PURCHASE2 & 0.833 & PRICE2 & 0.605 & PRODUCT2 & 0.889 \\
PURCHASE3 & 0.633 & PRICE3 & 0.700 & PRODUCT3 & 0.833 \\
PURCHASE4 & 0.714 & & & PRODUCT4 & 0.845 \\
\hline \multicolumn{2}{c}{ Communication strategy } & & \multicolumn{2}{c}{ Distribution strategy } \\
\hline \multicolumn{2}{c}{ Item } & & \multicolumn{2}{c}{ Item } \\
\hline COMUNICA1 & 0.814 & & DISTRIBU1 & 0.856 \\
COMUNICA2 & 0.838 & & & DISTRIBU2 & 0.818 \\
\hline
\end{tabular}

After internal consistency was obtained by Cronbach's Alpha, which is greater than 0.7 in all cases, this represents a good internal consistency according to the proposed by Nunnally (1967). As well as the convergent validity by average variance extracted (AVE) (see Table 2).

Table 2

Cronbach's Alpha and Convergent Validity

\begin{tabular}{lll}
\hline Construct & Cronbach's alpha $(\alpha)$ & Average variance extracted (AVE) \\
\hline Organic food purchase & 0.858 & 0.756 \\
Price strategies & 0.910 & 0.560 \\
Product strategies & 0.834 & 0.704 \\
Communication strategies & 0.883 & 0.800 \\
Distribution strategies & 0.914 & 0.689 \\
\hline
\end{tabular}


Discriminatory validity was also confirmed (see Table 3). In accordance with Fornell and Larcker (1981), a construct is equipped with discriminant validity if the average variance extracted a construct is greater than the squared correlations between this construct and others that make up the model and indicates that a construct is different from other. Indicators on the diagonal (in bold) represent the results of the square root of the AVE between constructs and measures. The indicators below the diagonal are correlations between constructs (Espejel \& Fandos, 2012, p. 120). In this sense, in order to fulfill the discriminant validity, indicators on the diagonal must be greater than the indicators under the same (Sanchez \& Roldan, 2005).

Table 3

Correlations

\begin{tabular}{llllll}
\hline Construct & $\begin{array}{l}\text { Organic food } \\
\text { purchase }\end{array}$ & Price strategy & Product strategy & $\begin{array}{l}\text { Communication } \\
\text { strategy }\end{array}$ & $\begin{array}{l}\text { Distribution } \\
\text { strategy }\end{array}$ \\
\hline Organic food purchase & $\mathbf{0 . 8 1 3}$ & - & - & - & - \\
Price strategies & 0.647 & $\mathbf{0 . 7 1 4}$ & - & - & - \\
Product strategies & 0.521 & 0.588 & $\mathbf{0 . 7 8 6}$ & - & - \\
Communication strategies & 0.642 & 0.393 & 0.629 & $\mathbf{0 . 8 2 4}$ & - \\
Distribution strategies & 0.655 & 0.658 & 0.567 & 0.734 & $\mathbf{0 . 8 1 4}$ \\
\hline
\end{tabular}

Note. Indicators on the diagonal (in bold) represent the results of the square root of AVE between constructs and measures. Coefficients are significant at a level of 95 percent.

As can be seen, it complies with the parameters described above. Finally we present the final model estimated (see Figure 2). The goodness of model fit is within the recommended limits (Goodness of Fit Index $(\mathrm{GFI})=0.961$; Comparative Fit Index $(\mathrm{CFI})=0.85$; Normed Fit Index $(\mathrm{NFI})=0.90$; Root Mean Square Error of Approximation $\left(\right.$ RMSEA) $=0.07$; Normed $X^{2}=150.86$ (68 degrees of freedom) with a $p<0.002$ ).

Of the four constructs related to the organic food purchase, two of them have a significant negative effect (price and communication strategies). Therefore, we rejected hypotheses 1 and 3, "The price has a positive and significant effect on organic foods purchase" $(-0.23, p<0.002)$; "The communication has a positive and significant effect on organic foods purchase” $(-0.10, p<0.002)$.

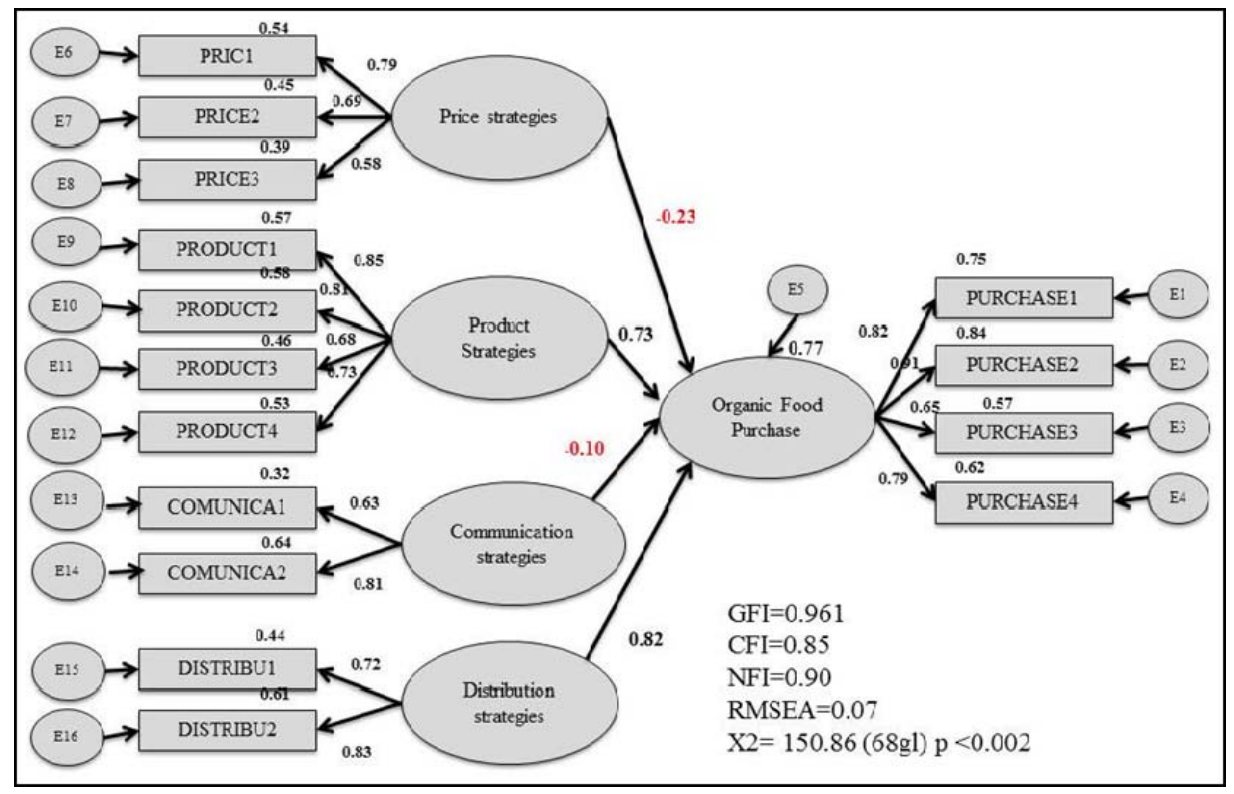

Figure 2. Estimated final structural model. 


\section{Conclusions}

This study provides market evidence on how to approach Mexican consumers, regarding marketing mix (price, product, and communication and distribution strategies) and its effects on organic food purchase.

Specifically, the results obtained in this study have shown a significant positive influence on product and distribution strategies towards organic food purchase. Mainly to evaluate product attributes such as health eight out of 10 Mexican consumers have purchased organic food by health similar as the results of the study of Horrigan et al. (2002).

The managerial implication of this study more relevant would focus on the importance for companies in Mexico to recognize that marketing strategy as noted Grundey and Zaharia (2008) are assets which have to invest more effort to accommodate them in the market for increasing organic foods purchase (p. 135). This requires strengthening the consumer perception in environmental communication, in all formats, be creative in expressing the relationship between a product/service and the environmental, presenting a corporate image of environmental responsibility, and promote an ecological lifestyle (Wagner \& Hansen, 2002, p. 20).

\section{References}

Azqueta, D. (2002). Introduction to environmental economics. Madrid, España: McGraw-Hill.

Banerjee, S., Gulas, C. S., \& Iyer, E. (1995). Shades of green: A multidimensional analysis of environmental advertising. Journal of Advertising, 24(2), 21-31.

Bansal, S. (2008). Choice and design of regulatory instruments in the presence of green consumers. Resource and Energy Economics, 30(3), 345-368.

Bazán Ramírez, A., Sánchez Hernández, B., Corral Verdugo, V., \& Castañeda Figueiras, S. (2006). Utilidad de los Modelos Estructurales en el Estudio de la Lectura y la Escritura. Revista Interamericana de Psicología, 40(1), 89-97.

Bentler, P. (1995). EQS structural equations program manual. Encino: Multivariate Software.

Bhaskaran, S., Polonsky, M., Cary, J., \& Fernandez, S. (2006). Environmentally sustainable food production and marketing Opportunity or hype? British Food Journal, 108(8), 677-690.

Bhate, S., \& Lawler, K. (1997). Environmentally friendly products: Factors that influence their adoption. Technovation, 17(8), 457-465.

Calomarde, J. V. (2000). Marketing ecológico. ESIC: Ed. Pirámide.

Carlson, L., \& Grove, S. J. (1996). Does environmental advertising reflect integrated marketing communications? An empirical investigation. Journal of Business Research, 37(3), 225-232.

Carlson, L., Grove, S. J., \& Kangun, N. (1993). A content analysis of environmental advertising claims: A matrix method approach. Journal of Advertising, 22(3), 27-40.

Chen, C. L. (2001). Design for the environment: A quality-based model for green product development. Management Science, 47(2), 250-263.

Chen, M. F. (2007). Consumer attitudes and purchase intentions in relation to organic foods in Taiwan: Moderating effects of food-related personality traits. Food Quality and Preference, 18, 1008-1021.

De Caluwe, N. (2004). Business benefits from applied ecodesign. IEEE Transactions on Electronics Packaging Manufacturing, 27(4), 215-220.

De Ferran, F., \& Grunert, K. G. (2007). French fair trade coffee buyers' purchasing motives: An exploratory study using means-end chains analysis. Food Quality and Preference, 18, 218-229.

Elzakker, B. V., \& Eyhorn, F. (2010). La guía de negocios orgánicos: Desarrollar cadenas de valor sostenibles con los pequeños agricultores. IFOAM: Primera edición.

Espejel-Blanco, J. E., \& Fandos-Herrera, C. (2012). Influencia de la confianza y el riesgo percibido por el consumidor en el comportamiento de intención compra hacia el vino somontano con DO. In L. Salgado Beltrán (Ed.), Memorias del I Congreso Internacional de Mercadotecnia (pp. 102-133). Universidad de Sonora, México.

Fornell, C., \& Larcker, D. F. (1981). Evaluating structural equation models with unobservable variables and measurement error. Journal of Marketing Research, 18(1), 39-50. 
Gifford, K., \& Bernard, J. C. (2011). The effect of information on consumers' willingness to pay for natural and organic chicken. International Journal of Consumer Studies, 35(3), 282-289.

Gómez-Cruz, M. A., Swentesius-Rinderman, R., Ortigoza-Rufino, J., \& Gómez-Tovar, L. (2009). Datos básicos de la agricultura orgánica de México. Sistema de Seguimiento e Información de la Agricultura Orgánica en México (p. 60). Universidad Autónoma de Chapingo, CIIDRI-CONACYT.

Govindasamy, R., \& Italia, J. (1999). Predicting willingness to pay a premium for organically grown fresh produce. Journal of Food Distribution Research, 30(2), 44-53.

Grundey, D., \& Zaharia, R. M. (2008). Sustainable incentives in marketing and strategic greening: The cases of Lithuania and Romania. Technological and Economic Development of Economy, 14(2), 130-143.

Handfield, R. B., Melnyk, S. A., Calantone, R. J., \& Curkovic, S. (2001). Integrating environmental concerns into the design process: The gap between theory and practice. IEEE Transactions on Engineering Management, 48(2), 189-209.

Hartmann, P., Apaolaza-Ibáñez, V., \& Forcada-Sainz, J. (2005). Green branding effects on attitude: Functional versus emotional positioning strategies. Marketing Intelligence and Planning, 23(1), 9-29.

Hawken, P. (1993). The ecology of commerce. New York: Harper Collins.

Horrigan, L., Lawrence, R. S., \& Walker, P. (2002). How sustainable agriculture can address the environmental and human health harms of industrial agriculture. Environmental Health Perspectives, 110(5), 445-456.

Jansen, A., \& Stevels, A. (2006). Combining eco-design and user benefits from human-powered energy systems, a win-win situation. Journal of Cleaner Production, 14(15-16), 1299-1306.

Lankard, A., \& Mclaughlin, W. J. (2003). Marketing an environmental issue: A case study of the wilderness society's core messages to promote national forest conservation from 1964 to 2000. Society and Natural Resources, 16(5), 415-434.

Lohr, L. (1998). Implications of organic cetification for market structure and trade. American Journal of Agricultural Economics, 80(5), 1125-1129.

Martinsons, M. G., So, S. K. K., Tin, C., \& Wong, D. (1997). Hong Kong and China: Emerging markets for environmental products and technologies. Long Range Planning, 30(2), 277-290.

Mathur, L. K., \& Mathur, I. (2000). An analysis of the wealth effects of green marketing strategies. Journal of Business Research, 50(2), 193-200.

Mohr, L. A., Eroglu, D., \& Ellen, P. S. (1998). The development and testing of a measure of skepticism toward environmental claims in marketers' communications. Journal of Consumer Affairs, 32(1), 30-55.

Montoro-Rios, F. J., Luque-Martínez, T., Fuentes-Moreno, F., \& Cañadas-Soriano, P. (2006). Improving attitudes toward brands with environmental associations: An experimental approach. Journal of Consumer Marketing, 23(1), 26-33.

Moon, W., Florkowski, W. J., Brückner, B., \& Schonhof, I. (2002). Willingness to pay for environmental practices: Implications for eco-labeling. Land Economics, 78(1), 15-88.

Nunnally, J. C. (1967). Psychometric theory. New York: McGraw Hill.

Ojala, M. (2008). Recycling and ambivalence quantitative and qualitative analyses of household recycling among young adults. Environment and Behavior, 40(6), 777-797.

Pujari, D., Wright, G., \& Peattie, K. (2003). Green and competitive-Influences on environmental new product development performance. Journal of Business Research, 56(8), 657-671.

Salgado-Beltrán, L., \& Beltrán-Morales, L. F. (2011). Factores que influyen en el consumo sustentable de productos orgánicos en el noroeste de México. Revista Universidad y Ciencia, 27(3), 3-8.

Salgado-Beltrán, L., Subirá-Lobera, M. E., \& Beltrán-Morales, L. F. (2009). La Compra Ecológica, una aproximación al comportamiento de los consumidores. Alemania: VDM Verlag.

Salgado-Beltrán, L., Subirá-Lobera, M. E., \& Beltrán-Morales, L. F. (2011). Factores Intrínsecos y extrínsecos de la compra ecológica. Revista Invurnus, 6(2), 265-279.

Sánchez, M. J., \& Roldán, J. L. (2005). Web acceptance and usage model: A comparison between goal-directed and experiential web users. Internet Research, 15(1), 21-48.

Schahn, J., \& Holzer, E. (1990). Studies of individual environmental concern-The role of knowledge, gender, and background variables. Environment and Behavior, 22(6), 767-786.

Schumacker, R. E., \& Lomax, R. (1996). A beginner's guide to structural equation modeling. New Jersey: Lawrence Erlbaum.

Schwentesius, R., Nelson, E., \& Gómez-Cruz, M. A. (2010). Producción orgánica y mercados locales en México. Retrieved from http://vinculando.org 
Stead, W. E., Stead, J. G., \& Worrell, D. L. (1991). Investigating the psychology of the green consumer. Psychological Reports, 68(3), 833-834.

Tung, S. J., Shih, C. C., Wei, S., \& Chen, Y. H. (2012). Attitudinal inconsistency toward organic food in relation to purchase intention and behavior an illustration of Taiwan consumers. British Food Journal, 114(7), 997-1015.

Wagner, E. R., \& Hansen, E. N. (2002). Methodology for evaluating green advertising of forest products in the United States: A content analysis. Forest Products Journal, 52(4), 17-24.

Wier, M. L., \& Mørch, A. (2001). Designing and testing the questionnaire-Results and considerations, Working Paper 3, Project on Consumer Demand for Organic Foods-Domestic and Foreign Market Perspectives, AKF, Denmark. 